\title{
Analisis Situasi Komunikatif Komunitas Bright Up Indonesia dimasa Pandemi Covid-19
}

\author{
Bright Up Indonesia Community Communicative Situation \\ Analysis during the Covid-19 Pandemic
}

\begin{tabular}{c} 
Fernindy Intan Putri ${ }^{1}$ \\
Zainal Abidin' \\
Ana Fitriana Poerana \\
${ }^{3}$ \\
Universitas Singaperbangsa Karawang \\
Alamat: J1. H.S Ronggo Waluyo, Peseurjaya, Kec. Teluk Jambe Timur, \\
Kabupaten Karawang, Jawa Barat, 41361 \\
${ }^{1}$ fernindy.intan17008@ student.unsika.ac.i; ${ }^{2}$ zainal.abidin@ fisip.unsika.ac.id, \\
${ }^{3}$ ana.fitriana@ fisip.unsika.ac.id \\
\hline
\end{tabular}

Dikirim: 15 Juni 2021, Direvisi: 23 Desember 2021, Diterima: 25 Desember 2021, Terbit: 31 Desember 2021. Sitasi: Putri, Abidin, Poerana, (2021) Analisis Situasi Komunikatif Komunitas Bright Up Indonesia dimasa Pandemi

Covid-19, PRoMEDIA. Volume 7 (2), Desember 2021, hal 345- hal 374.

\begin{abstract}
The Covid-19 pandemic has affected various aspects of human life, ranging from aspects of education, social, economy, tourism, and even the way humans communicate. During the Covid-19 pandemic, direct (face to face) communication is now no longer a main priority. The Bright Up Indonesia Community is a nonprofit social community has also felt the impact of change in communication culture during the Covid-19 pandemic. Where in current crisis, the Bright Up Indonesian community must be able to survive, adapt to technology, be creative and innovative in order to continue carrying out activities in accordance with organizational goals. The purpose of this research is to find out how "The communication event of Bright Up Indonesia Community during the Covid-19 Pandemic". This research uses a qualitative research method with a virtual ethnographic approach. The result of this research indicates a change in communication culture of community during the Covid-19 pandemic.
\end{abstract}




\title{
Keywords: Communication Cultures, Community, Pandemic Covid-19, CMC
}

\begin{abstract}
Abstraksi
Pandemi Covid-19 terbukti telah mempengaruhi berbagai aspek kehidupan manusia, mulai dari aspek pendidikan, sosial, ekonomi, pariwisata, bahkan cara manusia berkomunikasi. Bright Up Indonesia merupakan sebuah komunitas sosial bersifat non profit yang ikut merasakan dampak dari perubahan budaya komunikasi dimasa pandemi covid-19 ini. Dimana dalam kondisi krisis seperti saat ini komunitas Bright Up Indonesia harus bisa tetap survive, beradaptasi dengan teknologi, kreatif dan inovatif untuk tetap bisa menjalankan kegiatan sesuai dengan tujuan organisasinya. Tujuan dari penelitian ini adalah untuk mengetahui Bagaimana "Analisis Aktivitas Komunikasi Komunitas Bright Up Indonesia Dimasa Pandemi Covid-19". Penelitian ini menggunakan metode penelitian kualitatif dengan pendekatan etnografi virtual. Hasil dari penelitian ini menunjukkan adanya perubahan budaya komunikasi komunitas dimasa pandemi Covid-19..
\end{abstract}

\section{Kata Kunci: Budaya Komunikasi, Komunitas, Pandemi Covid-19, CMC}

\section{PENDAHULUAN}

Akhir tahun 2019 lalu, seluruh masyarakat dunia telah dihebohkan dengan kemunculan virus baru. Severe Acute Respiratory Syndrome Coronavirus 2 (SARS-CoV-2) atau lebih dikenal dengan nama virus Corona yang diduga berasal dari Kota Wuhan, China. Infeksi virus Corona disebut Covid-19 (Corona Virus Dease 2019), virus ini menular sangat cepat dan telah merambah keseluruh negara di dunia.

Covid-19 telah mempengaruhi segala sektor kehidupan manusia. Mulai dari sektor pendidikan, ekonomi, sosial, politik, 
budaya hingga cara manusia berkomunikasi. Sejumlah negara didunia menerapkan kebijakan lockdown serta membatasi kontak fisik untuk menekan laju penyebaran Covid-19, sehingga membuat orang-orang harus mengganti kebiasaan lama dengan kebiasaan baru untuk tetap terhubung satu sama lain dan saling berkomunikasi sebagai makhluk sosial yang membutuhkan bantuan orang lain. Semenjak mewabahnya kasus pandemi Covid-19 ini pula membuat komunikasi secara langsung (face to face) tidak lagi menjadi prioritas utama. Komunikasi dan interaksi dengan orang lain yang biasanya dilakukan secara langsung mau tidak mau harus digantikan dengan cara bertemu secara virtual (face to screen) di dunia maya ( Putri, 2020),

Transformasi perubahan gaya berkomunikasi dari sebelum adanya Pandemi Covid-19 ke setelah terjadinya Pandemi Covid-19 ini juga menjadi tantangan tersendiri bagi seluruh lapisan masyarakat. Sebagai contoh; kegiatan pendidikan yang biasanya dilakukan secara langsung di bangku sekolah maupun bangku kuliah harus diganti dengan cara belajar secara daring menggunakan internet, kegiatan berdagang yang biasanya dilakukan secara fisik/offline hingga kemudian para pedagang saat ini harus bisa beradaptasi dengan teknologi, memanfaatkan market place di internet maupun sosial media agar dapat bertahan ditengah pendemi Covid-19, berbagai pertemuan fisik juga digantikan dengan cara memanfaatkan sosial media maupun aplikasi meeting seperti: Zoom, Google Meet, Skype dan aplikasi 
sejenisnya, serta kegiatan pementasan atau pertunjukan seni juga ikut diselenggarakan secara virtual menggunakan kanal Youtube, Live Intsagram, maupun Zoom Meeting demi menghindari keruman manusia. Namun individu/ kelompok diharapkan tetap bisa menjalankan kegiatan seperti biasa sebagai mana mestinya secara virtual (Muslih, 2020).

Pada kesimpulannya, setiap kegiatan manusia sebisa mungkin dilaksanakan dari rumah dan secara tidak langsung hal ini membuat setiap individu harus menguasai dan memahami teknologi untuk tetap bisa berkomunikasi dalam memenuhi kebutuhan hidup masing-masing.

Perubahan gaya berkomunikasi di masa Pandemi Covid19 juga menjadi tantangan tersendiri bagi Komunitas Bright Up Indonesia. Bright Up Indonesia merupakan sebuah komunitas nonprofit yang bergerak dibidang sosial dalam meningkatkan mutu dan kualitas generasi muda Indonesia. Fokus dari komunitas Bright Up Indonesia ini adalah mengasah kemampuan soft skill dan hard skill anggota komunitas, mulai dari keterampilan public speaking, negosiation, lobbying, management event, public relations, media relations, serta keterampilan administratif.

Bright Up Indonesia didirikan sebagai wadah bagi generasi muda untuk berkolaborasi dan bekerjasama dalam menyatukan pikiran positif dan mewujudkannya kedalam sebuah kegiatan yang konkret serta berguna bagi masyarakat banyak. 
Berinovasi terhadap perubahan lingkungan dan menjadi gerakan sosial yang inspiratif. Berekspresi melalui segala media untuk menciptakan karakter muda yang ekspresif dan positif, serta berkreasi melalui kegiatan yang up to date dan sarat akan informasi. Pada kesimpulannya Bright Up Indonesia adalah komunitas sebagai wadah bagi generasi muda untuk berperan aktif dalam kegiatan sosial yang bermanfaat bagi masyarakat luas.

Pada mulanya, Bright Up Indonesia merupakan sebuah komunitas sosial yang tidak hanya aktif didunia maya namun juga sering melakukan pertemuan langsung rutin secara berkala. Pertemuan ini dilakukan pada hampir untuk seluruh kegiatan komunitas, mulai dari hanya sekedar brainstroaming untuk membangun ikatan emosional antar anggotanya, meeting event atau projek komunitas untuk menghindari miss communication dan juga menyatukan pendapat masing-masing anggota, hingga melaksanakan event secara offline disamping juga tetap melakukan komunikasi secara online melalui media sosial. Namun, komunikasi secara online tidak terlalu menjadi prioritas utama.

Ditengah masa krisis seperti saat ini, Komunitas Bright Up Indonesia dituntut untuk bisa beradaptasi dengan teknologi, lebih kreatif dan inovatif untuk menciptakan peluang dan berkolaborasi untuk mewujudkan tujuan organisasi agar tetap bisa berjalan sebagaimana mestinya. Terlebih lagi status Bright 
Up Indonesia sebagai komunitas sosial yang bersifat nonprofit, sehingga dibutuhkan kesadaran anggota yang tinggi untuk mewujudkan itu semua.

Belakangan ini hampir 99\% kegiatan komunitas dilakukan secara daring atau online menggunakan media sosial yang termediasi oleh internet. Kemunculan beberapa media sosial yang dijadikan media komunikasi membuatn pergerakan komunikasi tidak lagi terbatas pada jarak dan waktu. Perkembangan teknologi informasi ini tidak hanya mampu menciptakan masyarakat dunia global, tetapi juga secara materi membuka ruang hidup baru bagi masyarakat. Tanpa disadari, komunitas manusia hidup dalam dua dunia kehidupan, yakni kehidupan masyarakat nyata dan masyarakat maya (cybercommunity) di ranah virtual. Di dunia maya, komunikasi berlangsung melalui jejaring sosial berbasis online (Sitinjak, 2019).

Berdasarkan uraian diatas, hal inilah yang menjadi ketertarikan penulis untuk meneliti tentang "Analisis Aktivitas Komunikasi Komunitas Bright Up Indonesia dimasa Pandemi Covid-19" dengan menggunakan pendekatan etnografi virtual.

\section{A. Situasi Komunikatif}

Menurut Dell Hymes, situasi komunikatif adalah konteks terjadinya komunikasi. Engkus Kuswarno berpendapat bahwa komponen ini merujuk kepada konteks di mana komunikasi itu terjadi, misalnya dalam upacara, perkelahian, perburuan, pembelajaran di ruang kelas, konferensi, pesta, jamuan dan lain 
sebagainya. Situasinya bisa sama atau berbeda bergantung pada waktu, tempat dan keadaan fisik penutur secara keseluruhan (Fauziah, 2017)

Situasi Komunikatif merupakan salah satu unit diskrit dari aktivitas komunikasi. Bagi Hymes, tindak tutur atau tindak komunikatif mendapatkan statusnya dari konteks sosial, bentuk gramatika dan intonasinya. Sehingga level tindak tutur berada di antara level gramatika biasa dan peristiwa komunikatif atau situasi komunikatif dalam pengertian bahwa tindak tutur mempunyai implikasi bentuk linguistik dan norma-norma sosial (Kuswarno, 2008)

\section{B. Komunikasi Kelompok}

Pengertian komunikasi kelompok juga dinyatakan sebagai sekumpulan orang yang mempunyai tujuan bersama yang berinteraksi satu sama lain untuk mencapai tujuan bersama, mengenal satu sama lainnya dan memandang mereka sebagai bagian dari kelompok tesebut. (Mulyana, 2005)

Hal ini sesuai dengan fenomena yang terjadi saat komunitas Bright Up Indonesia melakukan sosialisasi tentang komunitasnya kepada member batch baru. Meskipun individu yang tergabung dalam batch tersebuh adalah anggota baru, namun para anggota lain tetap menganggap bahwa anggota tersebut merupakan anggota kelompok tanpa memandang lamanya dia bergabung dalam kelompok komunitas Bright Up Indonesia ini. 


\section{Computer Mediated Communication (CMC)}

Menurut Pixy Ferris secara general medefinisikan $C M C$ sebagai "interaksi secara interpersonal yang dihubungkan oleh komputer, yang meliputi komunikasi asynchronous dan synchronous melalui fasilitas dalam internet". Medium computer dalam CMC adalah berupa perangkat keras (hardware) dan perangkat lunak (software) berupa aplikasi khusus yang memungkinkan orang saling berinteraksi. Komputer harus memiliki jaringan Internet agar bisa saling terhubung dengan komputer lain secara global (Muffuddah, 2012)

Ada dua aspek dari $C M C$ yang membedakannya dengan komunikasi tatap muka, yaitu isyarat verbal (verbal cues) dan waktu yang lebih panjang (extended time) (Griffin, 2006)Berbeda dengan komunikasi tatap muka yang menggunakan simbolsimbol verbal (melalui bahasa oral) dan simbo-lsimbol nonverbal (melalui gestur tubuh), $C M C$ menggunakan sistem isyarat yang ada dalam aplikasi komputer, misalnya melalui emoticon (simbolsimbol berupa karakter teks yang mewakili ekspresi manusia dalam dunia online). Komunikasi yang terjadi dalam $C M C$ pun cenderung lebih lama dari komunikasi tatap muka. Komunikator dalam $C M C$ tidak dapat langsung memahami maksud pesan yang disampaikan karena terbatasi dengan karakter-karakter di komputer. Dalam kehidupan sehari-hari, untuk mencapai kebutuhan dalam mencari informasi serta melakukan interaksi, individu dapat melakukan melalui komunikasi tatap muka atau 
dengan menggunakan media. Dalam teori $C M C$, komunikasi yang dilakukan yaitu menggunakan komputer dengan internet (Griffin, 2006)

\section{Pola Komunikasi}

Pola komunikasi adalah suatu gambaran yang sederhana dari proses komunikasi yang memperlihatkan kaitan antara satu komponen komunikasi dengan komponen lainnya (Soejanto, 2001). Menurut Djamarah (2004) pola komunikasi dapat diartikan sebagai pola hubungan anatar dua orang atau lebih dalam pengiriman dan penerimaan pesan dengan cara yang tepat sehingga pesan yang ditujukan dapat dipahami maksudnya dengan baik (Khakamulloh, Mayasari dan Yusup, 2020)

Menurut Effendy ((Evan et al., 2017)) pola komunikasi terdiri atas 3 macam, yaitu komunikasi satu arah (one way) dimana komunikasi yang terjadi hanya satu arah, penyampaian pesan dari komunikator kepada komunikan baik menggunakan media ataupun tanpa media, tanpa ada umpan balik (feed back) dari komunikan, dalam hal ini komunikan hanya bertindak sebagai pendengar saja. Komunikasi dua arah (two way traffic communication) yaitu komunikator dan komunikan menjadi saling bertukar fungsi dalam menjalani fungsi mereka, komunikator pada tahap pertama menjadi komunikan dan pada tahap berikutnya saling berganti fungsi. Namun pada intinya yang menjadi pelaku percakapan adalah komunikator utama, komunikator utama mempunyai tujuan tertentu melalui proses 
komunikasi tersebut, prosesnya dialogis, serta umpan balik terjadi secara langsung. Komunikasi multi arah (all channels) komunikasi yang terjadi melibatkan lebih dari dua orang yang saling bertukar pikiran secara dialogis.

\section{METODOLOGI PENELITIAN}

Metode yang digunakan pada penelitian ini adalaha metode penelitian kualitatif. Kirk dan Miller (Moleong, 2002) mendefinisikan bahwa penelitian kualitatif adalah tradisi khusus dalam ilmu sosial, yang secara fundamental bergantung pada pengamatan manusia di wilayahnya sendiri dan pada hubungannya dalam diskusi dan terminologi. Objek penelitian kualitatif bersifat alamiah dan natural setting, sehingga metode penelitian ini bisa disebut dengan metode naturalistik. Objek alamiah yang diteliti merupakan objek apa adanya dan tidak dimanipulasi oleh peneliti, sehingga kondisi pada saat penelitian memasuki objek dan meninggalkan objek relative tidak berubah (Sugiyono, 2017).

\section{A. Jenis Penelitian}

Secara spesifik, pendekatan yang digunakan dalam penelitian ini adalah pendekatan etnografi virtual. Secara bahasa, etnografi berasal dari Bahasa Yunani gabungan kata ethos yang berarti warga suatu bangsa atau masyarakat dan kata graphein yang berarti tulisan atau artefak. Etnografi virtual merupakan metodologi yang digunakan untuk menyelidiki internet dan 
melakukan ekspolrasi terhadap entitas (user) saat menggunakan internet. Etnografi virtual juga merepresentasikan implikasiimplikasi dari komunitas yang termediasi oleh internet (Hine, 2000)

Dalam proses penggunaan etnografi virtual sebagai sebuah metode riset, terdapat beberapa prinsip dasar perlu ditekankan. Prinsip dasar ini terkait dengan konsep awal, bahwa Internet adalah bidang baru di mana entitasnya sama sekali berbeda dari realitas sosialnya di dunia nyata. Dalam hal ini, merujuk pada etnografi virtual yang dipopulerkan oleh Hine (2000), berikut prinsip-prinsip etnografi virtual:

1. Keberadaan peneliti di lapangan virtual. Di Internet, berdasarkan prinsip teknologi yang selalu hidup dan interaksi yang terjadi sepanjang waktu, keberadaan etnografer berbeda dengan penelitian etnografi di dunia nyata (lapangan). Lokasi di Internet juga merupakan lokasi yang unik, dengan proses dan struktur hierarki yang berbeda, serta akses menuju lokasi bisa menggunakan serangkaian perangkat smart phone, hardware, dan software. Kemudian, internet juga harus dilihat dalam konteks yang lebih luas. Internet bukan hanya sebagai media komunikasi antar penggunanya (user), tetapi juga tempat dimana komunitas berada dan berinteraksi, serta sebagai bentuk komunitas itu sendiri yang menjadi arsip virtual (Nasrullah, 2018: 25). 
2. Medium interaksi secara virtual. Internet menyediakan ruangan berbeda terhadap definisi interaksi antara entitas secara virtual. Praktik komunikasi tatap muka yang sudah ada dan diterapkan selama ini di dunia nyata berbeda secara konsep (teori) maupun prakterknya dengan komunikasi di dunia maya.

3. Medium komunikasi yang berkembang. Dalam etnografi virtual, etnografer harus memahami bagaiman proses interaksi antar entitas di media Internet terjadi.

4. Memahami lokasi dan koneksitas antar pengguna. Penelitian yang menggunakan etnografi virtual harus berangkat dari pemahaman umum tentang lokasi dan batas fisik atau geografis, dan harus berfokus pada arus dan konektivitas antara pengguna Internet.

5. Memberikan batasan. Seperti prinsip-prinsip sebelumnya, para etnografer masih perlu mengkaji di lapangan, karena di sinilah artefak budaya ada dan muncul. Namun proses interaksi antar entitas secara langsung maupun tidak, menempatkan lokasi sebagai bagian dari proses terbentuknya artefak kebudayaan.

6. Situasi sementara. Beralih dari lokasi nyata ke lokasi yang bersifat temporal dan secara nyata ke virtual, etnogafer harus memahami bahwa melakukan penelitian etnografi virtual adalah menginterprestasikan situasi sementara 
hasil dari berbaurnya etnografer dengan subjek penelitian di loaksi penelitian.

7. Menangkap artefak budaya yang parsial

8. Keterlibatan penuh dalam interaksi termediasi internet. Dalam hal ini, etnografer harus memahami teknologi yang digunakan entitas untuk berinteraksi dalam komunitasnya (Nasrullah, 2018)

9. Komunikasi virtual dan kehadiran entitas. Etnografi dan informan (penelitian) harus ada diantara keduanya (subjek penelitian). Bukan dalam konsepsi fisik, akan tetapi penggunaan teknologi dapat memediasi proses penelitian etnografi virtual.

\section{B. Pengumpulan Data}

Teknik pengumpulan data pada penelitian ini adalah sebagai berikut:

1. Observasi Tanpa Partisipan

Observasi tanpa pasrtisipan ini sangat cocok digunakan untuk mengetahui perilaku-perilaku atau kegiatan yang tidak memungkinkan peneliti atau etnografer untuk terlibat di dalamnya, misalnya untuk mengamati aktivitas anak-anak bermain, dinamika kelompok, dan sebagainya (Kuswarno, 2008)

2. Wawancara Mendalam

Wawancara etnografi virtual yang paling umum dan baik, adalah wawancara yang terdiri dari pertanyaan-pertanyaan 
yang tidak memiliki alternatif respon yang dtentukan sebelumnya. Atau yang lebih dikenal sebagai wawancara tidak terstruktur atau juga wawancara mendalam. Jenis wawancara ini akan mendorong subjek penelitian untuk mendefinisikan dirinya sendiri dari lingkungannya, untuk menggunakan istilah-istilah mereka sendiri mengenai objek penelitian.Studi Kepustakaan (Kuswarno, 2008)

Pada mulanya peneliti ingin melakukan wawancara mendalam secara langsung dalam proses pengumpulan data pada penelitian ini guna untuk mengamati perilaku informan secara langsung, akan tetapi karena beberapa faktor diluar kendali peneliti, seperti: informan yang sibuk, lokasi informan yang jauh, serta pembatasan pertemuan fisik sebagai dampak dari adanya pandemi Covid-19, sehingga peneliti memutuskan untuk melakukan wawancara mendalam secara online melalui aplikasi internet. Perubahan wawancara secara langsung dengan wawancara online tetap menggunakan kaidah aturan wawancara langsung sebagaimana mestinya.

3. Dokumentasi

Peneliti mengumpulkan data dari berbagai sosial media resmi Komunitas Bright Up Indonesia, serta dokumentasi kegiatan yang pernah diselenggakan oleh komunitas ini lalu disiarkan pada media massa untuk mendapatkan informasi yang terkait dengan penelitian.(Kurnia, 2020). 


\section{Penetuan Informan}

Informan dalam penelitian ini terpilih dari beberapa anggota Komunitas Bright Up Indonesia dengan menggunakan teknik purposive sampling, di mana teknik ini mencakup orangorang yang diseleksi atas dasar kriteria-kriteria tertentu yang dibuat penulis berdasarkan tujuan penelitian. Adapun kriteria yang ditetapkan dalam pemilihan informan kunci, pada penelitian ini adalah:

1. Pendiri komunitas Bright Up Indonesia

2. Ekulturasi penuh, artinya informan mengetahui secara baik budaya dalam komunitasnya

3. Keterlibatan langsung, artinya informan sering kali terlibat langsung dalam kegiatan yang dilakukan oleh komunitas.

4. Sudah pernah bergabung dalam Batch komunitas Bright Up Indonesia

5. Anggota aktif Komunitas Bright Up Indonesia baik pada batch yang sedang berlangsung maupn batch sebelumnya 
Sehingga informan yang peneliti maksud pada penelitian ini adalah:

Tabel 1. Daftar Nama Informan Penelitian

\begin{tabular}{|l|l|l|l|l|}
\hline No & \multicolumn{1}{|c|}{ Nama } & \multicolumn{1}{|c|}{ Pekerjaan } & Usia & \multicolumn{1}{|c|}{ Jabatan } \\
\hline $\mathbf{1}$ & $\begin{array}{l}\text { Imam } \\
\text { Suryanto }\end{array}$ & $\begin{array}{l}\text { Staff Humas } \\
\text { Kemendag }\end{array}$ & 30 & $\begin{array}{l}\text { Founder Bright Up } \\
\text { Indonesia }\end{array}$ \\
\hline $\mathbf{2}$ & $\begin{array}{l}\text { Rizky } \\
\text { Irawati }\end{array}$ & $\begin{array}{l}\text { Karyawan Amati } \\
\text { Indonesia }\end{array}$ & 24 & $\begin{array}{l}\text { Anggota batch 1 dan 2 } \\
\text { Komunitas Bright Up } \\
\text { Indonesia }\end{array}$ \\
\hline $\mathbf{3}$ & $\begin{array}{l}\text { Syifa Aulia } \\
\text { Putri }\end{array}$ & $\begin{array}{l}\text { Full Time Narasi TV } \\
\text { dan Freelance }\end{array}$ & 22 & $\begin{array}{l}\text { Anggota batch 2 } \\
\text { Komunitas Bright Up } \\
\text { Indonesia }\end{array}$ \\
\hline
\end{tabular}

\section{PEMBAHASAN}

\section{A. Analisis Situasi Komunikasi Komunitas Bright Up}

\section{Indonesia Secara langsung (face to face)}

Pada Mulanya Komunitas Bright Up Indonesia bukan hanya komunitas yang aktif di dunia online saja. Sebelum adanya Pandemi Covid-19 dan kegiatan Pembatasan Sosial Bersekala besar (PSBB), Komunitas Bright Up Indonesia juga kerap kali mengadakan kegiatan offline disamping juga selalu berkomunikasi secara online melalui media WhatsApp. Akan tetapi komunikasi online saat itu tidaklah menjadi alternatif komunikasi utama. Kegiatan offline yang sering dilakukan berupa meet up dan menyelenggarakan event offline, seperti seminar dan kegiatan santunan anak yatim.

Hal ini sesuai dengan pendapata informan Rizki:

"Semua ada plus minusnya sih menurut aku. Dulu sebelum ada pandemi kita sering ketemu langsung atau kita sering 
sebut meet up dua kali semingg gitu, trus ada event offline juga, waktu itu kita adain seminar di Perpusnas. Tapi setelah pandemi kita gaada komunikasi tatap muka lagi, sekarang semuanya serba online, bahkan kemaren welcoming batch 2 online sampai akhirnya farewell. Kalo mau meeting kita pake WhatsApp goup, Google Meet atau Zoom meeting. Plusnya sih kita lebih dekat sama teknologi ya, kalo dulu sebelum pandemi kita mana kenal apa itu Google Meet dan Zoom Meeting kan (Rizki Irawati, 5 Juni 2021)".

Siatusi komunikatif yang dimaksud pada penelitian ini adalah kegiatan meet up oleh komunitas Bright Up Indonesia. Dalam kegiatan meet up, tempat yang dijadikan sebagai pelaksanaan kegiatan adalah cafe, mall dan co-working space yang berada di daerah Jakarta dan sekitarnya. Tempat yang dipilih adalah hasil kesepakatan bersama anggota komunitas yang didiskusikan beberapa hari sebelum kegiatan meet up itu berlangsung. Kegiatan ini sendiri dilaksanakan sejak tahun 2019 awal. Biasanya kegiatan Meet Up ini dilaksanakan dalam kurun waktu 1 (satu) kali dalam dua minggu di akhir pekan (hari Sabtu atau Minggu).

Kegiatan meet up biasanya diawali dengan salam sapa antar anggota komunitas. Sambil menunggu anggota yang lain sampai dilokasi meet up, para anggota akan memulai interaksi secara personal dengan teman disampingnya, mulai dari hanya sekedar cerita perjalan menuju lokasi meet up, curhat-curhatan kecil tentang hal yang menjadi kesibukan masing-masing, hingga ajakan untuk membeli makanan atau minuman. 
Setelah semua anggota berkumpul, ketua komunitas atau salah satu kaka mentor pada komunitas tersebut akan membuka kegiatan meet up pada hari itu, setelah itu kegiatan meet up dilanjutkan dengan kegiatan bercerita atau story telling yang dilakukan oleh beberapa anggota komunitas yang telah ditunjuk sebelumnya, kemudian kegiatan dilanjutkan dengan sharing session atau sesi berbagi pengalaman yang disampaikan oleh kaka mentor atau guest star yang sengaja dihadirkan oleh kaka mentor dihari tersebut, setelah kegiatan sharing session selesai kegiatan dilanjutkan dengan membahas mengenai projek komunitas dan perkembangan komunitas, terakhir kegiatan meet up ini diakhiri dengan sesi foto bersama untuk keperluan dokumentasi komunitas (Rizki Irawati, 5 Juni2021).

Situasi Komunikatif pada kegiatan meet up dalam Komunitas Bright Up Indonesia pada tahap proses dimulai sampai dengan berakhirnya tidak akan berubah-ubah. Proses ini memang sudah menjadi kebiasaan atau budaya dalam komunitas tersebut. Tetapi untuk pelaksanaannya dapat berubah sesuai dengan situasi atau hal yang dibahasas dalam kegiatan meet up tersebut. Peristiwa komunikasi dinyatakan berakhir apabila komponen komunikasi berubah dan individu yang terlibat meninggalkan lokasi tersebut. 
Gambar 1. Suasana Kegiatan Meet Up Komunitas Bright Up

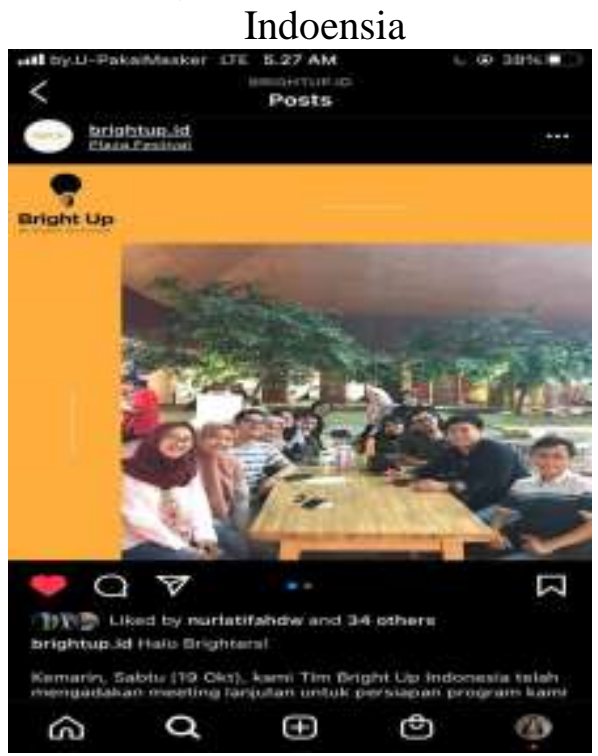

Sumber: Instagram Post Bright Up Indoesia, 2019

\section{B. Analisis Situasi Komunikatif Komunitas Bright Up \\ Indonesia di Dunia Virtual}

Dalam penelitian etnografi virtual konteks tentang aktivitas komunikasi yang diteliti tidak hanya komunikasi secara langsung atau tatap muka saja, akan tetapi etnografi komunikasi juga sangat erat kaitannya dengan komunitas manusia yang hidup dan berkembang diranah virtual. Dalam hal ini situasi komunikatif komunitas Bright Up Indonesia secara virtual pun perlu dibahas.

Ditengah krisis Pandemi Covid-19 yang tengah melanda Indonesia saat ini, salah satu cara yang dapat digunakan oleh manusia untuk bisa tetap terhubung dengan manusia lain adalah pemanfaatan internet sebagai media komunikasi. Media yang 
kerap kali digunakan oleh komunitas Brigt Up Indonesia untuk saling terhubung dan berkolaborasi mewujudkan tujuan komunitas adalah adalah WhatsApp, Google Meet, Zoom Meeting, Instaram dan Trello.

Hal ini sesuai dengan pendapat informan Syifa:

"Untuk media komunikasi yang yang sering digunain komunitas itu ada WhatsApp group, ini media utama ya. Kemudian untuk meeting yang harus nampilin wajah itu biasanya pake Zoom meet atau Google Meet, trus didivisi aku sendiri itu, divisi PR (public relations) biasanya kita juga pake Trello untuk nyimpenin rancangan ide dan hasil kerja kita. Untuk kegiatan branding dan juga event kita juga pake Instagram, sharing di IG live dan promosi kegiatan di postingan instagram Komunitas Bright Up Indonesia (Syifa Auli Putri, 8 Juni 2021).

Gambar 2. Dokumentasi Proses Wawancara dengan Informan Syifa

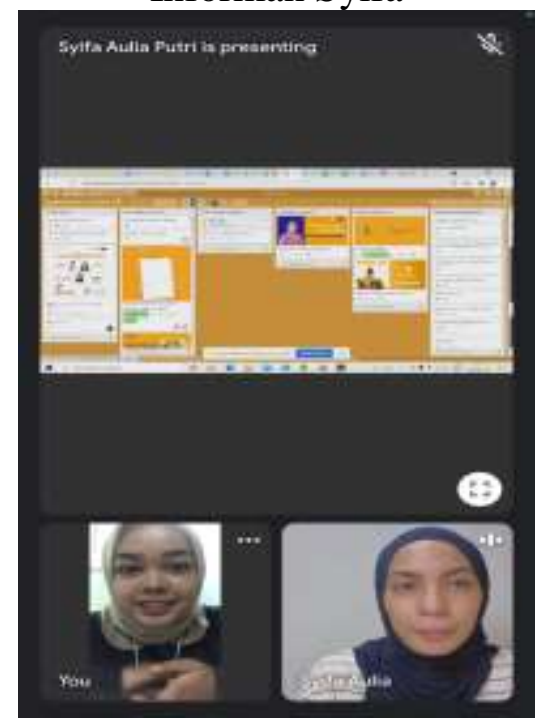

Sumber: Dokumentasi Peneliti, 2021 
Gambar 2. Ini merupakan situasi saat peneliti melakukan wawancara mendalam dengan informan Syifa pada tanggal 8 Juni 2021 lalu. Pada saat yang bersamaan Syifa menjelaskan aplikasi yang sering digunakan oleh komunitas Bright Up Indonesia untuk saling terhubung satu sama lain dimasa Pandemi Covid-19 ini, salah satu aplikasi atau website yang digunakan adalah Trello seperti gambar diatas.

Beragam media yang digunakan oleh Komunitas Bright Up Indonesia adalah bagian dari new media yang merupakan produk perkembangan internet dan CMC (Computer Mediated Communication). Menurut Van Dijk (2013) yang dikutip oleh Nasrullah New Media merupakan Sebuah platform media yang menitik beratkan pada kehadiran penggunanya yang mempromosikan kegiatan atau kolaborasi, karena media sosial dapat dikatakan sebagai media online (fasilitator). Media sosial dapat memperkuat hubungan pengguna melalui koneksi sosial (Nasrullah, 2017).

Situasi komunikatif virtual komunitas yang dimaksud adalah media utama yang digunakan sebagai media komunikasi pada komunitas tersebut. Berdasarkan keterangan informan Syifa, media komunikasi utama yang digunakan untuk menghubungkan anggota komunitas adalah WhatsApp Group. 
Gambar 3. Room Chat WhatsApp Group Komunitas

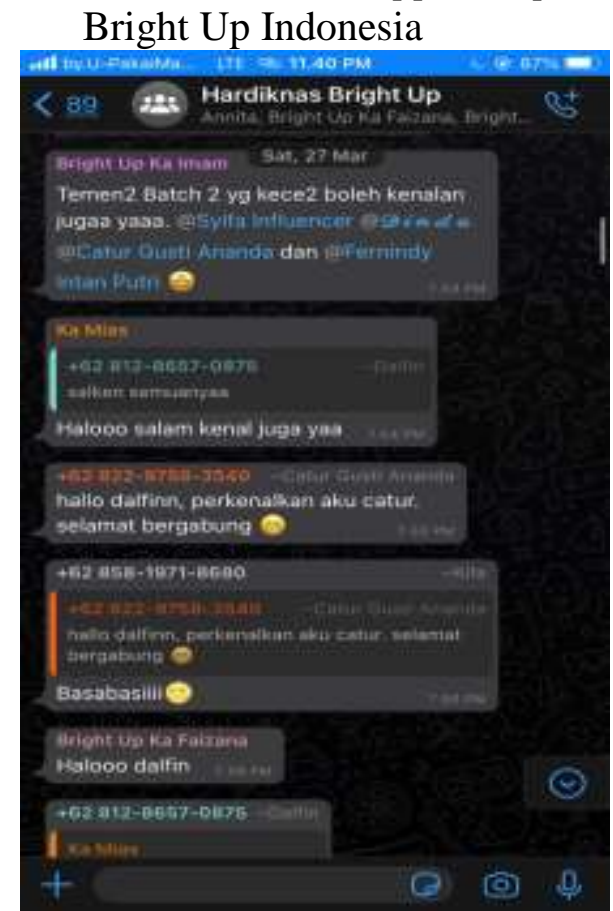

Sumber: Dokumentasi Peneliti, 2021

Seperti yang terlihat pada gambar diatas, Komunitas Bright Up Indonesia memanfaatkan WhtasApp Group sebagai media diskusi. WhatApp Group ini diberi nama "Hardiknas Bright Up" karena pada saat peneliti melakukan penelitian ini Komunitas Bright Up Indonesia sedang mempersiapkan rangkaian kegiatan (event) dalam rangka memperingati Hari Pendidikan Nasional (Hardiknas) 2021. Sebagai Komunitas sosial yang tumbuh dan berkembang dalam Negara Kesatuan Republik Indonesia, Komunitas Bright Up Indonesia merasa harus ikut andil dalam perayaan Hardiknas. Oleh karena itu, sesuai dengan visi dan misi komunitas, Bright Up Indonesia berkomitmen 
membuat penyelenggaraan Hardiknas demi menumbuhkan rasa nasionalisme dan cinta akan tanah air, Indonesia (Imam Suryanto, 27 April 2021).

Proses Komunikasi yang berlangsung pada WhatsApp Group Komunitas Bright Up Indonesia dimulai dari saling sapa antar anggota seperti yang terlihat pada gambar 3, kemudia media ini digunakan sebagai media diskusi anggota komunitas untuk membahas berbagai hal tentang komunitas, isu sosial, maupun program kerja komunitas.

Rangkaian kegiatan komunikasi yang terjadi pada WhatsApp group Bright Up Indonesia adalah ketua komunitas atau kaka mentor akan mendiskusikan tentang hari dan jam berapa rapat akan dimulai dengan para anggota komunitas lain. Hal ini dilakukan agar setiap anggota bisa mengukiti diskusi secara real-time pada saat jam yang telah ditentukan dan saling syncrhone (terhubung) pada saat itu juga. Setelah jam yang ditentukan tiba, ketua komunitas akan memberikan pengantar alur pembahasan diskusi, setiap anggota menyimak arahan tersebut. Setelah itu, para anggota juga diberikan kesempatan untuk memberikan masukan atau menyampaikan ide mengenai topik pembahasan tersebut. Setelah semua ide terkumpul, semua anggota komunitas akan mendiskusikan kembali ide apa saja yang relevan dengan kegiatan mereka, hingga akhirnya ditemukan beberapa poin gagasan yang kemudian di voting secara bersama. Setelah semuanya sepakat maka kaka mentor di 
komunitas tersebut akan memberikan pembagian tugas kepada anggota komunitas, mulai dari tugas administrasi (suratmenyurat, pembuatan ToR (Term of references), design pamflet kegiatan, campign kegiatan disosial media, tugas public relations dan tugas lain sesuai dengan divisi masing-masing anggota (Syifa Aulia Putri, 8 Juni 2021).

"stuggle kita kalo serba online sekarang mungkin menurut aku adalah meningkatkan kesadaran dan tanggung jawab tiap anggota ya, apalagi ini kan komunitas, dimana disini kita bener-bener ga dibayar sama sekali, nah kadang itu yang muncul di grup orangnya ko ini lagi ini lagi gitu, kalo ada projek trus mereka pada gaada respon tepaksa kita telfonin satu-satu kan, kalo mereka ga ngangkat ya yuadah, semua beban projek ada di kita yang aktif ajah, padahal kalo dibilang sibuk mah setiap orang punya kesibukan masing-masing gitu lo (Syifa Auli Putri, 8 Juni 2021)"

Diskusi di ranah virtual tentu berbeda dengan diskusi secara langsung (tatap muka), bedanya pada ranah virtual memiliki waktu yang lebih panjang (extended time), artinya jika pada jam atau hari tersebut para anggota belum merespon secara keseluruhan diskusi tersebut, maka diskusi dapat disrespon pada hari berikutnya atau bahkan diskusi tersebut dapat berlangsung dalam beberapa hari tanpa harus dimulai lagi secara formal rangkaian kegiatan dari awal lagi jika komunikasi yang terjalin masih dalam satu topik pembahasan. 
Gambar 4. Situasi Komunikatif Room Chat WhatsApp Group Komunitas Bright Up Indonesia Dalam Mengambil Keputusan

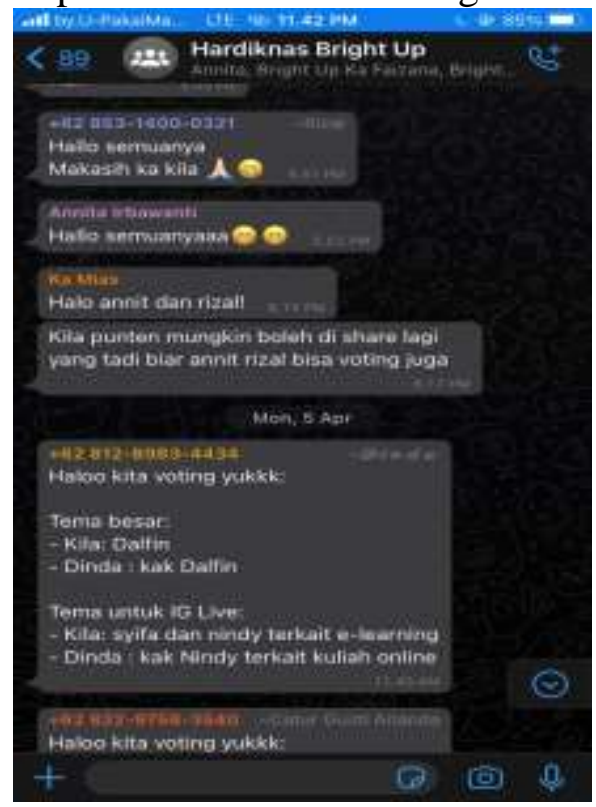

Sumber: Dokumentasi Peneliti 2021

\section{Pola Komunikasi Komunitas Bright Up Indonesia}

Mengidentifikasi pola komunikasi dalam penelitian etnografi sama saja dengan menjelaskan pemolaan komunikasi melalui kategori-kategori ujaran. Kategori ujaran adalah pengelompokan peristiwa dan tindak komunikatif ke dalam setting tertentu, atau hubungan antara komponen-komponen komunikasi dalam setting komunikasi tertentu (Kuswarno, 2008)

Peristiwa komunikatif yang ada dalam Komunitas Bright Up Indonesia adalah menentuakan situasi komunikatif atau konteks terjadinya komunikasi. Berdasarkan hasil observasi tanpa partisipan dan didukung dengan hasil wawancara dengan 
narasumber, bahwa budaya meet up biasanya diselenggarakan di mall, co-working space, dan café yang berada di daerah Jakarta, untuk tempat sendiri dipilih secara random oleh anggota komunitas melalui kesepakatan bersama. Pada tempat itulah anggota komunitas saling berinteraksi satu sama lain.

Genre atau tipe peristiwa komunikatif merupakan komponen yang mengacu pada bentuk penyampaian pesan yang terjadi seperti lelucon, salam perkenalan, gosip dan sebagainya. Tipe peristiwa yang terjadi di dalam kegiatan meet up yaitu diawali dengan mengatakan say hello dan salaman antar anggota komunitas. Karena salam ini menggambarkan keramahan dan keakraban yang terjalin antar anggota komunitas. Kehadiran dan kelengkapan anggota merupakan penentu kegiatan meet up akan dimulai, dan biasanya akan dimulai jika forum telah memenuhi kuota partisipan. Di dalam kopdar ini, hal yang rutin dibahas dan diperbincangkan yaitu mengenai kegiatan internal komunitas maupun yang ada di luar komunitas. Dari pembahasan tersebut biasanya menimbulkan sebuah ajang diskusi kelompok (discussion group), yang nantinya hasil dari pembahasan ini merupakan hasil yang disepakati bersama oleh semua anggota komunitas yang hadir.

Berdasarkan keterangan diatas, Maka pola komunikasi yang terjadi di dalam meet up Komunitas Bright Up Indonesia yaitu menggunakan pola komunikasi multi arah (all channels) karena di dalam kegiatan meet up terdapat lebih dari dua individu 
yang terlibat di dalam proses komunikasi. Dan di kegiatan meet up juga menggunakan sistem diskusi kelompok dalam melakukan proses komunikasi. Dimana masing-masing individu dapat menjadi komunikator dan komunikan dalam proses komunikasi yang terjadi secara dialogis. Hal yang sama juga pada terjadi dalam komunikasi secara virtual, dimana Komunitas Bright Up Indonesia menggunakan WhatsApp group untuk berdiskusi, menyampaikan ide dan gagasan, serta voting untuk mengambil keputusan bersama (Imam suryanto, 27 April 2021).

\section{KESIMPULAN DAN SARAN}

\section{A. Kesimpulan}

Peneliti berasumsi bahwa konteks yang dimaksud dalam situasi komunikatif pada Komunitas Bright Up Indonesia ini adalah kegiatan meet up pada komunitas serta aplikasi yang sering digunakan dalam berkomunikasi secara virtual dengan anggota komunitas, yaitu WhatsApp group. Semenjak munculnya Pandemi Covid-19, komunitas Bright Up Indonesia dituntut untuk bisa menguasai teknologi, karena dimasa krisis ini komunikasi secara langsung tidak lagi dapat menjadi alternatif komunikasi utama, sehingga Komunitas Bright Up Indonesia memanfaatkan beragam aplikasi yang ada di internet, seperti Zoom Meeting, WhatsApp, Google Meet, Trello, Instagram, dan Youtube. Hal ini dilakukan agar komunitas dapat berjalan sebagaimana mestinya sesuai dengan tujuan organisasi. Maka, situasi komunikatif yang 
terjadi berupa diskusi kelompok yang berlangsung antar anggota komunitas yang berjumlah lebih dari dua orang. sehingga dapat disimpulkan pola komunikasi yang digunakan adalah pola komunikasi multi arah (all channels), baik diskusi secara langsung mapun secara virtual.

\section{B. Saran}

Komunitas Bright Up Indonesia diharapkan lebih kreatif dan inovatif lagi dalam memanfaatkan teknologi yang ada sebagai alternatif komunikasi di masa Pandemi Covid-19, berinovasi dalam membuat konten kreatif untuk menjangkau lebih banyak lagi target audiens komunitas, membuat alternatif kegiatan yang dapat membangun kedekatan antar anggota komunitas, serta membuat aturan yang tegas bagi anggota yang kurang aktif dan lari dari tanggung jawab selama menjabat dalam kepengurusan komunitas, hal ini bertujuan untuk meningkatkan kesadaran tiap anggota dan juga menghindari pemusatan pekerjaan pada satu orang saja. 


\section{DAFTAR PUSTAKA}

Evan, J. dkk. 2017.Pola Komunikasi Pada Komunitas Hammers Bandung Pattern Of Communication Hammers Bandung Community. Bandung: Telkom University.

Fauziah, S. 2017. Studi Etnografi Komunikasi Ritul Adat Masyarakat Kampung Pulo Desa Cangkuang Kecamatan Leles Kabupaten Garut Provinsi Jawa Barat. Skripsi. Jakarta: UIN Syarif Hidayatullah.

Griffin, E. 2006. A First Look at Communication Theory. London: McGraw Hill.

Hine, C. 2000. Virtual Ethnography. London: UK: SAGE Publications.

Khakamulloh, M., Mayasari dan Yusup, E. 2020. Analisis pola komunikasi budaya ngopi di komunitas Karawang Menyeduh. Bandung: UNPAD.

Kurnia, N. S. 2020. Aktivitas blogging pada komunitas blogger perempuan Network. Bandung: UNIKOM.

Kuswarno, E. 2008 Metode Penelitian Komunkasi Etnografi Komunikasi. Bandung: Widya Padjadjaran.

Muffuddah, A. A. 2012. Penggunaan Media Sosial Sebagai Media Komunikasi Di Kalangan Mahasiswa (Studi pada Mahasiswa Jurusan Ilmu Komunikasi Fakultas Ilmu Sosial dan Ilmu Politik Universitas Brawijaya Malang Pengguna Facebook, Twitter, Foursquare, dan Flickr. Malang : Universitas Brawijaya.

Mulyana, D. 2005. Komunikasi Antar Budaya. Bandung: PT. Remaja Rosda Karya. 
Muslih, B. 2020. Urgensi Komunikasi dalam Menumbuhkan Motivasi di Era Pandemi Covid-19. Kediri: Universitas Nusantara PGRI Kediri.

Nasrullah, R. 2017. Media Sosial Perspektif Komunikasi, Budaya, dan Sosioteknologi. Bandung: Simbiosa Rekatama Media.

Nasrullah, R. 2018. Etnografi Virtual, Riset Komunikasi, Budaya, Dan Sosioteknologi. Bandung: Simbiosa Rekatama Media.

Putri, F. 2020 . Budaya Komunikasi Virtual Pada Masa Pandemi Covid-19. Semarang: UIN Walisongo Semarang.

Sitinjak, M. L. 2019. Pengaruh Media Sosial Whatsapp Terhadap Kebutuhan Afiliasi Komunitas Orang Muda Katolik (Omk) Gereja Katolik Santa Maria Pekanbaru, Jom Fisip. Pekan Baru: UNRI.

Sugiyono. 2017. Metode Penelitian Kualitatif. Bandung: Alfabeta. 